\title{
Investigating Potential Modes of Actions of Mimusops kummel Fruit Extract and Solvent Fractions for Their Antidiarrheal Activities in Mice
}

\author{
Mulugeta Molla, ${ }^{1}$ Negero Gemeda, ${ }^{2}$ and Solomon M. Abay ${ }^{3}$ \\ ${ }^{1}$ School of Pharmacy, College of Health and Medical Sciences, Haramaya University, Haramaya, Ethiopia \\ ${ }^{2}$ Traditional and Modern Medicine Research Directorate, Ethiopian Public Health Institute, Addis Ababa, Ethiopia \\ ${ }^{3}$ Department of Pharmacology, School of Medicine, College of Health Sciences, Addis Ababa University, Addis Ababa, Ethiopia
}

Correspondence should be addressed to Solomon M. Abay; solomonabay@gmail.com

Received 13 February 2017; Accepted 19 April 2017; Published 9 May 2017

Academic Editor: Raffaele Capasso

Copyright (C) 2017 Mulugeta Molla et al. This is an open access article distributed under the Creative Commons Attribution License, which permits unrestricted use, distribution, and reproduction in any medium, provided the original work is properly cited.

Background. Fruits of Mimusops kummel A. DC. (Sapotaceae) are traditionally used for the treatment of diarrhea. The present study aimed at investigating modes of actions of this fruits for antidiarrheal action to guide future drug development process. Methods. Fractions of chloroform, n-butanol, and water were obtained from $80 \%$ methanol extract, which was prepared by maceration. Antidiarrheal activities and the modes of actions were investigated in mice. Results. In castor oil induced diarrheal model, the extract delayed onset of diarrhea and reduced number and weight of feces at all tested doses significantly. In this model all fractions significantly delayed onset of diarrhea at all tested doses. Charcoal meal test showed that the extract and all the fractions produced a significant antimotility effect at all tested doses. Enteropooling test showed that the extract as well as n-butanol and aqueous fractions at all tested doses produced a significant decline in volume and weight of intestinal contents, whereas chloroform fraction had substantial effect only at high dose. Conclusion. This study demonstrated that the extract and solvent fractions produced antidiarrheal activities due to dual inhibitory effect, intestinal motility, and fluid secretion, with the aqueous fraction being the most active among fractions in three models.

\section{Background}

Diarrheal illness is a serious public health problem that affects all regions of the world and all ages $[1,2]$. Diarrhea is a state of reversal of normal net absorption of water and electrolyte, absorption to secretion [3]. There are many etiologic factors of diarrhea, but infection is the most common cause. Infectious diarrhea occurs because of food and water contamination via the fecal-oral route [4]. The main enteric pathogens include a wide range of bacteria (e.g., diarrheagenic Escherichia coli, nontyphoidal Salmonella, Shigella spp., Vibrio cholera, and Campylobacter spp.), virus (e.g., rotavirus group A, norovirus, Sapovirus, astrovirus, adenovirus, and enterovirus), and enteric parasites (e.g., Cryptosporidium spp., Giardia lamblia, Entamoeba histolytica, and Blastocystis hominis) [2].
In addition to fluid and electrolyte replacement, pharmacologic interventions like adsorbents (e.g., attapulgite), antimotility agents (e.g., loperamide), antisecretory agents (e.g., octreotide), and anti-infective agents (e.g., fluoroquinolones) are the conventional options in the treatment of diarrheal diseases $[5,6]$. Rotavirus vaccines included in national immunization programs [7] and a vaccine for cholera that could be useful in some settings in all ages have also been available for several years [1]. For the already available tools used to treat or prevent diarrhea, there are product specific issues: safety concerns with the live attenuated vaccines [8] and increasing rate of microbial resistance to the approved anti-infective drugs $[9,10]$. For instance, a study in Cambodia showed that $100 \%$ of Shigella isolates were resistant to trimetho$\mathrm{prim} / \mathrm{sulfamethoxazole}$, which is one of the conventional agents to treat diarrhea [11]. 
Despite the development of vast spectrum of western medicine approaches for the management of diarrhea, several studies show the reliance of people in developing countries on traditional medicine to intervene the sign and symptoms of diarrhea $[12,13]$. This practice may be attributed partly due to the inadequacy and inaccessibility of modern health services [14]. In relation to the indigenous practice, ethnobotany studies show that different types of plant materials are traditionally used for the treatment of diarrhea, among which there are fruits of M. kummel A. DC. (Sapotaceae) $[12,13,15]$.

M. kummel is a deciduous small-to medium-sized tree up to $35 \mathrm{~m}$ high, containing latex, with bole up to $100 \mathrm{~cm}$ in diameter, bark deeply grooved, dark grey, crown dense, ovoid, and young densely red brown pubescent branches. Leaves arranged spirally, more or less in tufts at the ends of branches. Its fruit is an ellipsoid to ovoid berry up to $2.5 \mathrm{~cm}$ long, orange-red when being ripe, containing a single large seed [16]. M. kummel fruits are principally used in Ethiopia for the treatment of diarrhea and amebiasis [15]. Similarly, the seeds are used to treat ascariasis [16].

An experimental study from Kenya showed that organic solvent extracts of $M$. kummel have antimicrobial activity [17], particularly Pseudomonas aeruginosa (causing nosocomial diarrhea) [18]. The same study reveals the presence of sesquiterpene lactones, flavonoids, alkaloids, and saponins in the methanol extract of $M$. kummel stem. Another study from Cote d'Ivoire reports antischistosomal activity of hydroethanol extract of $M$. kummel stem bark. Activity of this extract against newly transformed schistosomula was higher than the activity against an adult worm [19].

The prior reports of antibacterial [17] and antiparasitic [19] activities support use of M. kummel fruit in the treatment of diarrhea in Ethiopia. This evidence warrants studies on other responsible modes of action (antimotility and antisecretory) for its antidiarrheal activity, which is conducted using animal models that mimic the pathogenesis of diarrheal illness in human being $[20,21]$. To this effect, it is necessary to establish scientific evidence for therapeutic use of M. kummel, as it may potentially be useful source of new lead compounds to be input for the drug development process or give a clue about the strategies of standardized medicinal plant remedy. The present study, therefore, aimed at evaluating the mode of antidiarrheal activity of the $80 \%$ methanol extract of $M$. kummel fruits $(80 \% \mathrm{MeOH}-\mathrm{E})$ and solvent fractions in mice model.

\section{Materials and Methods}

2.1. Collection and Preparation of Plant Materials. Fresh ripe fruits of M. kummel were collected from Sisa, Dera Woreda, Amhara region, located about $595 \mathrm{~km}$ north of the capital Addis Ababa, Ethiopia, in November 2015. Botanical identification and authentication were done by senior botanist (Dr. Getachew Addis) at the Traditional and Modern Medicine Research Directorate, Ethiopian Public Health Institute (EPHI). A voucher specimen (number MM-01) was deposited at the institute's herbarium for future reference. The fruits were initially washed using distilled water to remove dust materials and dried at room temperature under shade for 14 days. The fruits were then chopped into small pieces and ground into coarse powder using a porcelain mortar and pestle. The powder was stored at room temperature in air sealed polythene bags until extraction commenced.

\subsection{Extraction and Fractionation}

2.2.1. Preparation of $80 \%$ Methanol Extract. Hydromethanol (80\%) extract was prepared by cold maceration technique. Briefly, $500 \mathrm{~g}$ of coarse fruit powder in a conical flask was mixed with $2.5 \mathrm{~L}$ of $80 \%$ methanol. The flask with its contents was sealed and kept for a period of $48 \mathrm{~h}$ at room temperature accompanying intermittent shaking using miniorbital shaker (Bibby Scientific Limited, Stone, Staffordshire, UK) revolving at $120 \mathrm{rpm}$ to enhance the efficient extraction. The entire mixture was first filtered through a funnel plunged with muslin cloth two times and then the filtrate was passed through Whatman filter paper (Number 1) (Maidstone, UK). After filtration, the residue was remacerated two times for a total of $96 \mathrm{~h}$ in order to obtain a better yield. The marc was pressed and the combined filtrate was then concentrated using a rotary evaporator (Buchi Model R-200, Switzerland) set at $40^{\circ} \mathrm{C}$. The concentrate was pooled together and freezedried using a lyophilizer (Operan, Korea Vacuum Limited, Korea). It rendered a solid residue of yellowish color which was designated as $80 \% \mathrm{MeOH}-\mathrm{E}$ and stored in an air tight container in deep freezer $\left(-20^{\circ} \mathrm{C}\right)$ until being used for further investigation.

2.2.2. Fractionation of Crude Extract. Solvent fractionation of crude extract was carried out using water, chloroform, and n-butanol. Briefly, eighty grams of the crude extract was dissolved in $400 \mathrm{~mL}$ of distilled water and this solution was transferred to a separating funnel. An equal volume of chloroform was added to it and was shaken vigorously. The mixture was separated in two layers. The chloroform layer (lower) was then removed. The partition with chloroform was repeated two times. All of the chloroform layers were combined and subjected to evaporation using a rotary evaporator (Buchi Model R-200, Switzerland) set at $40^{\circ} \mathrm{C}$ to get the chloroform fraction, and then the filtrate was placed in an oven at $45^{\circ} \mathrm{C}$ for one week to remove the remaining solvent. To the separating funnel containing aqueous layer, $400 \mathrm{~mL}$ of $\mathrm{n}$-butanol was added. The upper layer in this case was n-butanol, which was separated and the procedure was repeated two times. The separated n-butanol layers were pooled and concentrated using a rotary evaporator (Buchi model R-200, Switzerland) set at $40^{\circ} \mathrm{C}$ to obtain the n-butanol fraction, and then the filtrate was placed in an oven at $45^{\circ} \mathrm{C}$ for two weeks to remove the remaining solvent. The remaining aqueous layer (lower in this case) was concentrated in a lyophilizer (Operan, Korea Vacuum Limited, Korea) to remove water. After drying, the solvent fractions were stored in an air tight container in refrigerator until being used for evaluation of the antidiarrheal activity and phytochemical constituents. 
2.2.3. Experimental Animals. Swiss albino mice of either sex, weighing 25-30 $\mathrm{g}$ and aged 6-8 weeks, obtained from Animal Breading Unit of EPHI were used for the experiment. Five to eight animals were housed in polyethylene cages having metallic cover and woodchip bedding. They were maintained at a $12 \mathrm{~h}$ light-dark cycle, ambient room temperature, and had free access to standard pellet diet and water. The animals, handled according to the guideline for the care and use of experimental animals [22], were acclimatized to laboratory condition-Pharmacology Laboratory of the Traditional and Modern Medicine Research Directorate, EPHI-for one week before being subjected to experimental protocol [23]. Ethical approval for the conduct of the research project was obtained from the Scientific and Ethics Committee of the Department of Pharmacology, School of Medicine, Addis Ababa University.

2.2.4. Animal Grouping and Dosing. In all the three experimental models, animals were randomly assigned by research assistant into groups (a negative control group, three test groups, and a positive control group) comprising of six animals per group. All groups were provided with their respective treatments using oral gavage. The negative control groups received vehicle at a volume of $10 \mathrm{~mL} / \mathrm{kg}$ body weight (distilled water only for control group in $80 \% \mathrm{MeOH}-\mathrm{E}$ assessment or $2 \%$ Tween 80 in distilled water for the control group in chloroform, n-butanol, and aqueous fractions category). The test groups received 100, 200, and $400 \mathrm{mg} / \mathrm{kg}$ of the $80 \% \mathrm{MeOH}-\mathrm{E}$ or solvent fractions of M. kummel orally, while the positive group received standard drug (loperamide, $3 \mathrm{mg} / \mathrm{kg}$ ) orally. Loperamide served as a standard drug for castor oil induced diarrhea, small intestine transit time, and enteropooling models. Dose selection was made based on the results from acute oral toxicity test as well as pilot study using 8 experimental animals. Doses of 100, 200, and $400 \mathrm{mg} / \mathrm{kg}$ were designated as low, moderate, and high dose, respectively, in the present study. Stock solutions were prepared freshly on the day of experiment.

\subsection{Determination of In Vivo Antidiarrheal Activity}

2.3.1. Castor Oil Induced Diarrhea Model. A method described by Maniyar et al. [24] was followed for the current study. In this experiment, Swiss albino mice of either sex were deprived of food for $18 \mathrm{~h}$ with free access to water and divided randomly into groups of six mice each. The negative control group received $10 \mathrm{~mL} / \mathrm{kg}$ of distilled water (control for $80 \% \mathrm{MeOH}-\mathrm{E}$ ) or $2 \%$ Tween 80 in distilled water (control for fraction groups) and the test groups received 100,200 , and $400 \mathrm{mg} / \mathrm{kg}$ body weight of $80 \% \mathrm{MeOH}-\mathrm{E}$ or solvent fractions while the positive control group was given loperamide $3 \mathrm{mg} / \mathrm{kg}$ orally. Separate control groups for $80 \%$ $\mathrm{MeOH}$ and fractions were arranged because of the difference in solubility between crude extracts and fractions. After $1 \mathrm{~h}$ of treatment with the vehicles or test drugs, diarrhea was induced by administration of $0.5 \mathrm{~mL}$ of castor oil orally to each mouse. The experimental animals were then placed individually in cages with a white paper lined floor to collect fecal matters. The transparent paper was changed every $h$ for a total of $4 \mathrm{~h}$. During the observation period of $4 \mathrm{~h}$, onset of diarrhea (the time interval in minutes between administration of castor oil and appearance of the first diarrheal stool), number and weight of wet stools, and total number and weight of fecal output were recorded for individual mouse. Finally, percentages of diarrheal inhibition, weight of wet, and total fecal output were calculated using formulas described as follows $[25,26]$ :

Percentage of inhibition (\%)

$$
\begin{aligned}
= & \frac{\text { Mean number of WFC }- \text { Mean number of WFT }}{\text { Mean number of WFC }} \\
& \times 100,
\end{aligned}
$$

where WFC is wet feces in control group and WFT is wet feces in test group.

Percentage of wet fecal output (\%)

$$
\begin{aligned}
& =\frac{\text { Mean weight of wet feces of each treatment group }}{\text { Mean weight of wet feces of control }} \\
& \quad \times 100 \text {, }
\end{aligned}
$$

Percentage of total fecal output (\%)

$$
=\frac{\text { Mean fecal weight of each treatment group }}{\text { Mean fecal weight of control }} \times 100 \text {. }
$$

2.3.2. Castor Oil Induced Gastrointestinal Motility Test. Gastrointestinal transit (motility) was investigated in mice using the method mentioned somewhere [27]. Before commencement of the experiment, mice were fasted for $18 \mathrm{~h}$ but allowed free access to water and randomly allocated into groups of six animals in each group to determine the effect of $80 \% \mathrm{MeOH}-\mathrm{E}$ and fractions on gastrointestinal transit of a marker meal. Mice received distilled water or $2 \%$ Tween 80 in distilled water $(10 \mathrm{~mL} / \mathrm{kg}), 80 \% \mathrm{MeOH}-\mathrm{E}$ or solvent fractions $(100,200$, and $400 \mathrm{mg} / \mathrm{kg})$, and standard drug (loperamide $3 \mathrm{mg} / \mathrm{kg}$ ) orally. After an hour of dosing, all of the mice were challenged with $0.5 \mathrm{~mL}$ of castor oil perorally to induce diarrhea. Then, $1 \mathrm{~mL}$ of charcoal meal (5\% activated charcoal suspension in distilled water) was given orally an hour after castor oil administration. Thirty minutes later each mouse was then humanly sacrificed by cervical dislocation and small intestine was immediately dissected out from pylorus to caecum and placed length wise on a white paper. Distance travelled by the charcoal meal from pylorus and total length of the intestine were measured. Peristaltic index (PI) expressed as percentage of the distance travelled by the charcoal meal relative to the total length of the small intestine 
as well as percentage of inhibition of movement as a function of the control was calculated using the following formulas:

Peristaltic index (PI)

$$
\begin{aligned}
= & \frac{\text { Mean distance travelled by charcoal meal }}{\text { Mean length of small intestine }} \\
& \times 100,
\end{aligned}
$$

$$
\text { Percentage of inhibition }(\%)=\frac{(\mathrm{Dc}-\mathrm{Dt})}{\mathrm{Dc}} \times 100 \text {, }
$$

where Dc is mean distance travelled by the charcoal in the control group and Dt is mean distance travelled by the charcoal in the test group.

2.3.3. Castor Oil Induced Enteropooling Test. Effects of $80 \%$ $\mathrm{MeOH}-\mathrm{E}$ and solvent fractions on intraluminal fluid accumulation were determined using a method described by Degu and colleagues [28]. Prior to the experiment, the animals of either sex were fasted for $18 \mathrm{~h}$ and randomly divided into groups consisting of six mice in each group; they were pretreated with distilled water or $2 \%$ Tween 80 in distilled water $(10 \mathrm{~mL} / \mathrm{kg})$, extract or fractions $(100,200$, and $400 \mathrm{mg} / \mathrm{kg}$ ), and standard drug (loperamide $3 \mathrm{mg} / \mathrm{kg}$ ) orally. After $1 \mathrm{~h}$ of treatment, $0.5 \mathrm{~mL}$ of castor oil was given and animals were sacrificed by cervical dislocation $1 \mathrm{~h}$ following castor oil administration. The abdomen of each animal was then opened; the small intestine was removed, tied with thread at pyloric end and ileocaecal junction. The dissected small intestine was weighed and intestinal contents were then collected by milking into a graduated tube and their volume was measured. Weight of the intestine after milking was taken and the difference between full and empty intestines was calculated. Finally, percentage of inhibitions of intestinal secretion (volume and weight) by the extract or fractions were estimated relative to the negative control using the following formulas:

$$
\begin{aligned}
& \text { Percentage of inhibition by using MVIC } \\
& =\frac{\text { MVICC }- \text { MVICT }}{\text { MVICC }} \times 100,
\end{aligned}
$$

where MVICC is mean volume of intestinal content of control group and MVICT is mean volume of intestinal content of test group.

Percentage of inhibition by using MWIC

$$
=\frac{\text { MWICC }- \text { MWICT }}{\text { MWICC }} \times 100 \text {, }
$$

where MWICC is mean weight of intestinal content of control group and MWICT is mean weight of intestinal content of test group.

2.3.4. Estimation of In Vivo Antidiarrheal Index. The in vivo antidiarrheal index (ADI) for $80 \% \mathrm{MeOH}-\mathrm{E}$ and solvent fractions was determined by combining three parameters taken from the aforementioned models. It was then expressed according to the following formula [29]:

$$
\begin{aligned}
& \text { In vivo antidiarrheal index }(\mathrm{ADI}) \\
& =\sqrt[3]{\text { Dfreq } \times \text { Gmeq } \times \text { Pfreq }},
\end{aligned}
$$

where Dfreq is the delay in defecation time as percentage of negative control, Gmeq is the gut meal travel reduction as percentage of negative control, and Pfreq is the reduction in purging frequency in the number of wet stools as percentage of negative control.

2.3.5. Preliminary Phytochemical Screening. The crude extract as well as chloroform, n-butanol, and aqueous fractions of $M$. kummel fruits was tested for the presence of various phytochemical classes of compounds such as anthraquinones, tannins, saponins, flavonoids, terpenoids, alkaloids, glycosides, steroids, and phenols using previously described methods [30-32].

2.3.6. Acute Oral Toxicity Test. Acute oral toxicity test for $80 \%$ $\mathrm{MeOH}-\mathrm{E}$ of $M$. kummel fruits was performed according to the Organization for Economic Cooperation and Development (OECD) guideline 425 [33]. Five female albino mice of 6-8 weeks were used for each test. All mice were fasted (food but not water) for $4 \mathrm{~h}$ before and $2 \mathrm{~h}$ after the administration of the extract. First, a sighting study was performed to determine the starting dose. For this, a single female mouse was given $2000 \mathrm{mg} / \mathrm{kg}$ of the extract as a single dose by oral gavage. Since no death was observed within $24 \mathrm{~h}$, additional four mice were used and administered the same dose of the extract. The animals were housed separately in cages and observed continuously for $4 \mathrm{~h}$ in $30 \mathrm{~min}$ interval and then for 14 consecutive days with an interval of $24 \mathrm{~h}$ for the general signs and symptoms of toxicity, food and water intake, and mortality.

2.4. Data Analysis. Data were analyzed using Statistical Package for Social Sciences, version 20. Experimental results obtained from this study were expressed as mean $\pm \mathrm{CI}_{95}$ (95\% confidence interval). The statistical analysis of data was done using one-way analysis of variance followed by Tukey's post hoc test for multiple comparisons, which was used to compare results among groups. Differences were considered statistically significant if $p$ values were less than 0.05 . Linear regression analysis was applied to assess dose dependency nature of antidiarrheal effect.

\section{Results}

3.1. Effect of M. kummel Fruits on Castor Oil Induced Diarrheal Model. In the course of observation for $4 \mathrm{~h}$ after castor oil administration, as presented in Table 1, the $80 \% \mathrm{MeOH}-\mathrm{E}$ of the fruits of $M$. kummel significantly delayed the onset of diarrhea and reduced the number and weight of wet and total stools at doses of $100 \mathrm{mg} / \mathrm{kg}(p<0.05), 200 \mathrm{mg} / \mathrm{kg}$ $(p<0.05)$, and $400 \mathrm{mg} / \mathrm{kg}(p<0.05)$ as compared with the 


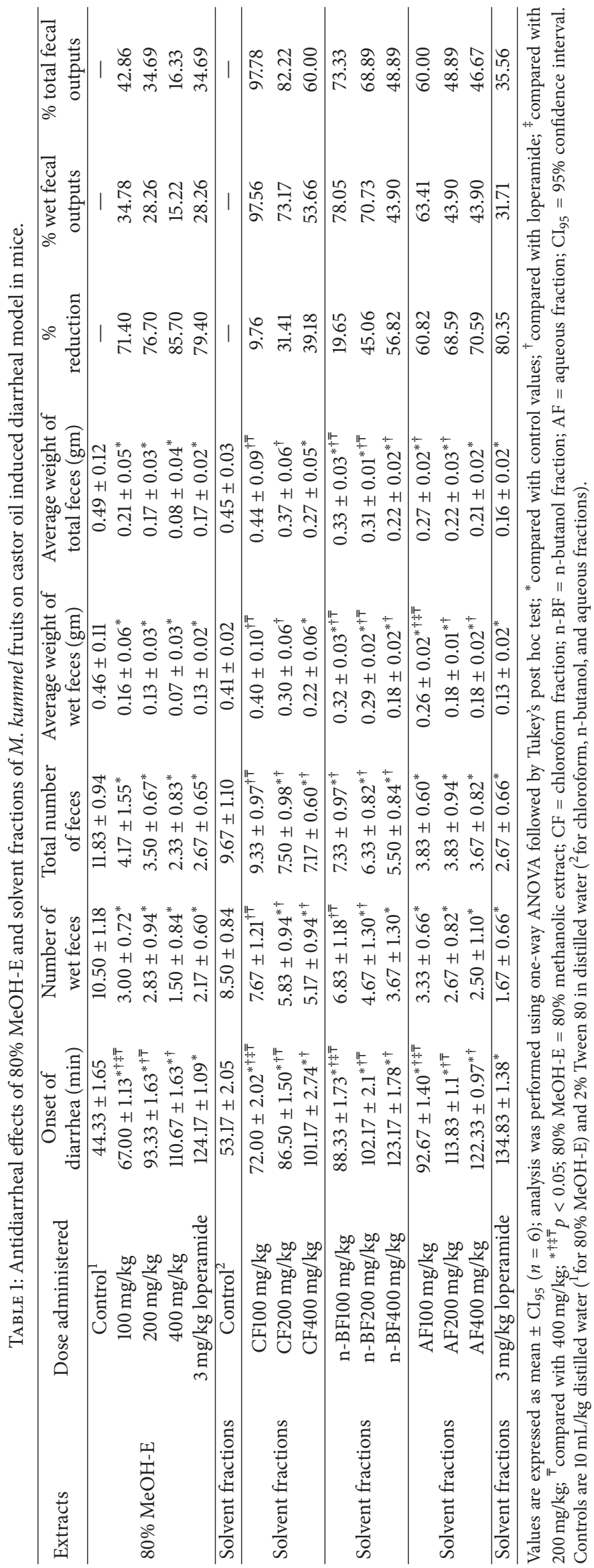


TABLE 2: Effects of $80 \% \mathrm{MeOH}-\mathrm{E}$ and solvent fractions of $M$. kummel fruits on castor oil induced gastrointestinal motility in mice.

\begin{tabular}{|c|c|c|c|c|c|}
\hline Extracts & Dose administered & $\begin{array}{l}\text { Length of small intestine } \\
(\mathrm{cm})\end{array}$ & $\begin{array}{l}\text { Distance moved by the } \\
\text { charcoal meal }(\mathrm{cm})\end{array}$ & Peristaltic index (\%) & $\%$ inhibition \\
\hline \multirow{5}{*}{$80 \% \mathrm{MeOH}-\mathrm{E}$} & Control $^{1}$ & $56.83 \pm 0.79$ & $45.67 \pm 0.97$ & $80.36 \pm 1.76$ & - \\
\hline & $100 \mathrm{mg} / \mathrm{kg}$ & $52.50 \pm 1.10$ & $19.33 \pm 0.97^{* \dagger \neq \bar{\top}}$ & $36.81 \pm 1.39^{* \dagger \neq \bar{\top}}$ & 57.66 \\
\hline & $200 \mathrm{mg} / \mathrm{kg}$ & $53.67 \pm 0.97$ & $16.83 \pm 0.94^{* \bar{\top}}$ & $31.35 \pm 1.35^{* \bar{\top}}$ & 63.14 \\
\hline & $400 \mathrm{mg} / \mathrm{kg}$ & $57.50 \pm 0.84$ & $14.17 \pm 1.18^{*}$ & $24.64 \pm 2.05^{*}$ & 68.98 \\
\hline & $3 \mathrm{mg} / \mathrm{kg}$ loperamide & $58.67 \pm 0.97$ & $15.50 \pm 0.84^{*}$ & $26.42 \pm 1.29^{*}$ & 66.06 \\
\hline Solvent fractions & Control $^{2}$ & $55.17 \pm 1.38$ & $47.83 \pm 0.94$ & $86.74 \pm 1.76$ & - \\
\hline \multirow{3}{*}{ Solvent fractions } & $\mathrm{CF} 100 \mathrm{mg} / \mathrm{kg}$ & $53.67 \pm 1.49$ & $42.17 \pm 1.71^{* \dagger \pm \bar{\top}}$ & $78.56 \pm 2.02^{* \dagger \neq \bar{T}}$ & 11.83 \\
\hline & CF200 mg/kg & $54.83 \pm 1.55$ & $36.00 \pm 1.43^{* \dagger \overline{\mathrm{T}}}$ & $65.64 \pm 1.50^{* \dagger \bar{\top}}$ & 24.73 \\
\hline & $\mathrm{CF} 400 \mathrm{mg} / \mathrm{kg}$ & $54.67 \pm 1.30$ & $32.50 \pm 1.50^{* \dagger}$ & $59.42 \pm 1.55^{* \dagger}$ & 32.05 \\
\hline \multirow{3}{*}{ Solvent fractions } & $\mathrm{n}-\mathrm{BF} 100 \mathrm{mg} / \mathrm{kg}$ & $55.83 \pm 0.94$ & $38.67 \pm 0.97^{* \dagger \ddagger \bar{T}}$ & $69.31 \pm 2.73^{* \dagger \neq \bar{\top}}$ & 19.15 \\
\hline & $\mathrm{n}-\mathrm{BF} 200 \mathrm{mg} / \mathrm{kg}$ & $55.67 \pm 1.40$ & $33.00 \pm 1.68^{* \dagger \bar{\top}}$ & $59.24 \pm 1.74^{* \dagger \bar{\top}}$ & 31.06 \\
\hline & $\mathrm{n}-\mathrm{BF} 400 \mathrm{mg} / \mathrm{kg}$ & $54.17 \pm 1.18$ & $27.67 \pm 1.40^{* \dagger}$ & $51.05 \pm 1.72^{* \dagger}$ & 42.20 \\
\hline \multirow{3}{*}{ Solvent fractions } & $\mathrm{AF} 100 \mathrm{mg} / \mathrm{kg}$ & $55.17 \pm 0.94$ & $30.17 \pm 1.18^{* \dagger \neq \bar{\top}}$ & $54.74 \pm 2.90^{* \dagger \neq \overline{\mathrm{T}}}$ & 36.92 \\
\hline & $\mathrm{AF} 200 \mathrm{mg} / \mathrm{kg}$ & $55.83 \pm 0.94$ & $24.17 \pm 0.94^{* \dagger \overline{\mathrm{T}}}$ & $43.30 \pm 1.92^{* \dagger \bar{\top}}$ & 49.47 \\
\hline & $\mathrm{AF} 400 \mathrm{mg} / \mathrm{kg}$ & $55.00 \pm 1.13$ & $20.83 \pm 1.18^{* \dagger}$ & $37.87 \pm 1.90^{* \dagger}$ & 56.45 \\
\hline Solvent fractions & $3 \mathrm{mg} / \mathrm{kg}$ loperamide & $55.50 \pm 0.84$ & $17.33 \pm 0.97^{*}$ & $31.23 \pm 1.66^{*}$ & 63.77 \\
\hline
\end{tabular}

Values are expressed as mean $\pm \mathrm{CI}_{95}(n=6)$; analysis was performed using one-way ANOVA followed by Tukey's post hoc test; ${ }^{*}$ compared with control values; ${ }^{\dagger}$ compared with loperamide; ${ }^{\ddagger}$ compared with $200 \mathrm{mg} / \mathrm{kg}$; ${ }^{\bar{\top}}$ compared with $400 \mathrm{mg} / \mathrm{kg} ;{ }^{* \dagger \dagger}{ }^{\dagger \bar{T}} p<0.05 ; 80 \% \mathrm{MeOH}-\mathrm{E}=80 \%$ methanolic extract; $\mathrm{CF}=$ chloroform fraction; $\mathrm{n}-\mathrm{BF}=\mathrm{n}$-butanol fraction; $\mathrm{AF}=$ aqueous fraction; $\mathrm{CI}_{95}=95 \%$ confidence interval. Controls are $10 \mathrm{~mL} / \mathrm{kg}$ distilled water $\left({ }^{1}\right.$ for $\left.80 \% \mathrm{MeOH}-\mathrm{E}\right)$ and $2 \%$ Tween 80 in distilled water ( ${ }^{2}$ for chloroform, n-butanol, and aqueous fractions).

negative control. Besides, the data revealed that percentage of diarrheal inhibitions were $71.40 \%(p<0.05), 76.70 \%$ $(p<0.05)$, and $85.70 \%(p<0.05)$ at the doses of 100 , 200 , and $400 \mathrm{mg} / \mathrm{kg}$, respectively. The maximum dose of this extract $(400 \mathrm{mg} / \mathrm{kg})$ produced the maximum percentage of inhibition of defecation and the lowest percentage of mean fecal output when compared with the tested doses of the extract and positive control.

Data from the experiment revealed that percentage of diarrheal inhibitions obtained as compared with control were $60.82 \%(p<0.05), 68.59 \%(p<0.05)$, and $70.59 \%$ $(p<0.05)$ at the doses of 100,200 , and $400 \mathrm{mg} / \mathrm{kg}$ aqueous fractions, respectively. The aqueous fraction also showed a significant reduction in weight of both wet and total fecal output at $100 \mathrm{mg} / \mathrm{kg}(p<0.05), 200 \mathrm{mg} / \mathrm{kg}(p<0.05)$, and $400 \mathrm{mg} / \mathrm{kg}(p<0.05)$ when compared with the negative control. Similarly, the n-butanol fraction significantly decreased the frequency and weight of wet and total feces at doses of $200 \mathrm{mg} / \mathrm{kg}(p<0.05)$ and $400 \mathrm{mg} / \mathrm{kg}(p<$ $0.05)$, with the highest percentage of diarrheal inhibition $(56.82 \%, p<0.05)$ obtained at the latter dose of this fraction compared with the negative control. The chloroform fraction had significant antidiarrheal activity on castor oil induced diarrhea as compared with the negative control $(p<0.05)$, with lower value at $100 \mathrm{mg} / \mathrm{kg}$ and $200 \mathrm{mg} / \mathrm{kg}$ doses compared with the other two fractions. In addition, $100 \mathrm{mg} / \mathrm{kg}$ and $200 \mathrm{mg} / \mathrm{kg}$ chloroform fraction did not have any significant effect on weight of wet and total fecal outputs.

As depicted in Table 1, there was a dose-dependent reduction in the percentage of weight of wet and total fecal outputs in $80 \% \mathrm{MeOH}-\mathrm{E}\left(R^{2}=1.000 ; R^{2}=0.997, p<0.05\right)$, chloroform fraction $\left(R^{2}=0.939 ; R^{2}=0.992, p<0.05\right)$, and n-butanol fraction $\left(R^{2}=0.984 ; R^{2}=0.974, p<0.05\right)$, respectively, with $400 \mathrm{mg} / \mathrm{kg}$ of the $80 \% \mathrm{MeOH}-\mathrm{E}$ displaying the highest effect (15.22\% and 16.33\%). As compared with the standard drug (28.26\% and $34.69 \%)$, the $80 \% \mathrm{MeOH}-\mathrm{E}$ at its $400 \mathrm{mg} / \mathrm{kg}$ revealed the greatest impact on the percentage of fecal output.

\subsection{Effect of M. kummel Fruits on Castor Oil Induced Gastroin-} testinal Motility. As presented in Table 2, the $80 \% \mathrm{MeOH}-$ E significantly inhibited the intestinal transit of charcoal meal at all tested doses. The percentage of reduction of gastrointestinal transit of charcoal was 57.66\% $(p<0.05)$, $63.14 \%(p<0.05)$, and $68.98 \%(p<0.05)$ at doses of 100 , 200 , and $400 \mathrm{mg} / \mathrm{kg}$, respectively. The activity of $80 \% \mathrm{MeOH}-$ $\mathrm{E}$ at $400 \mathrm{mg} / \mathrm{kg}$ was comparable to that of the standard drug, loperamide $(66.06 \%$ at the dose of $3 \mathrm{mg} / \mathrm{kg})$.

All the three fractions of fruits of $M$. kummel significantly inhibited gastrointestinal motility of charcoal meal at all tested doses as compared with vehicle treated group. The maximum effect was achieved by the aqueous fraction at $400 \mathrm{mg} / \mathrm{kg}$ with the charcoal meal traversing $56.45 \%$ of the total length of the small intestine (Table 2).

\subsection{Effect of M. kummel Fruits on Castor Oil Induced Intestinal} Secretion. In the gastrointestinal enteropooling test, $80 \%$ $\mathrm{MeOH}-\mathrm{E}$ of M. kummel fruits showed significant reduction in both average volume (except the low dose, $100 \mathrm{mg} / \mathrm{kg}$ ) and 
TABLE 3: Effects of $80 \% \mathrm{MeOH}-\mathrm{E}$ and solvent fractions of the fruits of $M$. kummel on castor oil induced enteropooling in mice.

\begin{tabular}{|c|c|c|c|c|c|}
\hline Extracts & Dose administered & $\begin{array}{l}\text { Mean volume of small } \\
\text { intestinal content (gm) }\end{array}$ & $\%$ inhibition & $\begin{array}{c}\text { Mean weight of small } \\
\text { intestinal content }(\mathrm{mL})\end{array}$ & $\%$ inhibition \\
\hline \multirow{5}{*}{$80 \% \mathrm{MeOH}-\mathrm{E}$} & Control $^{1}$ & $0.85 \pm 0.08$ & - & $1.21 \pm 0.10$ & - \\
\hline & $100 \mathrm{mg} / \mathrm{kg}$ & $0.63 \pm 0.11$ & 25.49 & $1.02 \pm 0.17^{* \dagger \ddagger \overline{\bar{T}}}$ & 15.63 \\
\hline & $200 \mathrm{mg} / \mathrm{kg}$ & $0.52 \pm 0.13^{*}$ & 39.22 & $0.80 \pm 0.02^{*}$ & 33.61 \\
\hline & $400 \mathrm{mg} / \mathrm{kg}$ & $0.42 \pm 0.09^{*}$ & 50.98 & $0.69 \pm 0.01^{*}$ & 43.02 \\
\hline & $3 \mathrm{mg} / \mathrm{kg}$ loperamide & $0.45 \pm 0.11^{*}$ & 47.06 & $0.71 \pm 0.01^{*}$ & 41.36 \\
\hline Solvent fractions & Control $^{2}$ & $0.87 \pm 0.10$ & - & $0.99 \pm 0.10$ & - \\
\hline \multirow{3}{*}{ Solvent fractions } & $\mathrm{CF} 100 \mathrm{mg} / \mathrm{kg}$ & $0.75 \pm 0.11^{\dagger \overline{\mathrm{T}}}$ & 13.79 & $0.83 \pm 0.07^{\dagger}$ & 16.16 \\
\hline & $\mathrm{CF} 200 \mathrm{mg} / \mathrm{kg}$ & $0.57 \pm 0.10^{\dagger}$ & 34.48 & $0.72 \pm 0.10^{\dagger}$ & 27.30 \\
\hline & $\mathrm{CF} 400 \mathrm{mg} / \mathrm{kg}$ & $0.50 \pm 0.11^{*}$ & 42.53 & $0.67 \pm 0.10^{* \dagger}$ & 32.33 \\
\hline \multirow{3}{*}{ Solvent fractions } & $\mathrm{n}-\mathrm{BF} 100 \mathrm{mg} / \mathrm{kg}$ & $0.63 \pm 0.11^{* \dagger \bar{\top}}$ & 27.59 & $0.70 \pm 0.10^{* \dagger \bar{\top}}$ & 29.31 \\
\hline & $\mathrm{n}-\mathrm{BF} 200 \mathrm{mg} / \mathrm{kg}$ & $0.58 \pm 0.12^{* \dagger}$ & 33.32 & $0.60 \pm 0.02^{* \dagger}$ & 39.40 \\
\hline & $\mathrm{n}-\mathrm{BF} 400 \mathrm{mg} / \mathrm{kg}$ & $0.37 \pm 0.11^{*}$ & 57.47 & $0.53 \pm 0.08^{*}$ & 46.45 \\
\hline \multirow{3}{*}{ Solvent fractions } & $\mathrm{AF} 100 \mathrm{mg} / \mathrm{kg}$ & $0.53 \pm 0.08^{* \dagger}$ & 39.08 & $0.63 \pm 0.02^{* \dagger \bar{\top}}$ & 36.35 \\
\hline & $\mathrm{AF} 200 \mathrm{mg} / \mathrm{kg}$ & $0.42 \pm 0.10^{*}$ & 51.72 & $0.54 \pm 0.02^{* \dagger}$ & 45.50 \\
\hline & $\mathrm{AF} 400 \mathrm{mg} / \mathrm{kg}$ & $0.38 \pm 0.12^{*}$ & 56.32 & $0.45 \pm 0.03^{*}$ & 54.53 \\
\hline Solvent fractions & $3 \mathrm{mg} / \mathrm{kg}$ loperamide & $0.30 \pm 0.07^{*}$ & 60.91 & $0.42 \pm 0.04^{*}$ & 57.58 \\
\hline
\end{tabular}

weight of intestinal contents at all tested doses as compared with the negative control $(p<0.05)$ (Table 3$)$.

The aqueous and n-butanol fractions reduced the volume and weight of the intestinal contents significantly at all tested doses. Maximum percentage of inhibition of the volume of intestinal contents was observed at $400 \mathrm{mg} / \mathrm{kg}$, being $56.32 \%$ $(p<0.05)$ and $57.47 \%(p<0.05)$ for aqueous and n-butanol fractions, respectively. The chloroform fraction was devoid of any significant inhibitory effect on the volume and weight of intestinal contents up to $200 \mathrm{mg} / \mathrm{kg}$ as compared with the negative control (Table 3 ).

3.4. Effect of M. kummel Fruits on In Vivo Antidiarrheal Index. Estimates of in vivo ADI revealed that the greatest value was achieved at the dose of $400 \mathrm{mg} / \mathrm{kg}$ of $80 \% \mathrm{MeOH}-\mathrm{E}(96.00 \%)$ which is comparable to the standard drug, loperamide at the dose of $3 \mathrm{mg} / \mathrm{kg}$ (98.12\%). Among all solvent fractions, aqueous fraction showed the highest in vivo ADI $(80.33 \%)$ at the dose $400 \mathrm{mg} / \mathrm{kg}$. Both $80 \% \mathrm{MeOH}-\mathrm{E}$ and solvent fractions showed dose-dependent increment in ADI value: $80 \% \mathrm{MeOH}-\mathrm{E}\left(R^{2}=0.913\right)$, chloroform fraction $\left(R^{2}=0.887\right)$, n-butanol fraction $\left(R^{2}=0.941\right)$, and aqueous fraction $\left(R^{2}=\right.$ 0.832) (Table 4).

3.5. Preliminary Phytochemical Screening Results. Preliminary phytochemical screening of the $80 \% \mathrm{MeOH}-\mathrm{E}$ of $M$. kummel fruits revealed the presence of alkaloids, saponins, tannins, phenols, terpenoids, and flavonoids. Steroids, anthraquinones, and glycosides were absent in $80 \% \mathrm{MeOH}-$ $\mathrm{E}$ of the plant. Among the solvent fractions, only the aqueous fraction tested positive for flavonoids. On the other hand, saponins and tannins were detected in both aqueous and n-butanol fractions. Phenols were common across all solvent fractions. Terpenoids were observed in both chloroform and n-butanol fractions. Among the three fractions, the aqueous fraction appeared to be qualitatively rich in secondary metabolites as shown from Table 5.

3.6. Acute Oral Toxicity Test. Eighty percent of methanol extract of the fruits of M. kummel was studied for oral acute toxicity at dose of $2000 \mathrm{mg} / \mathrm{kg}$ by oral route. The extract produced no mortality and any apparent signs of toxicity when observed for first $4 \mathrm{~h}$ with $30 \mathrm{~min}$ interval and followed by daily observations for 14 days following oral administration of a single dose of $2000 \mathrm{mg} / \mathrm{kg}$. In addition, neither food nor water intake was found to be reduced during the period of 14 days. The absence of mortality and signs of overt toxicity up to five times the maximum effective dose of the extract used in the experiment suggested that $80 \%$ $\mathrm{MeOH}-\mathrm{E}$ has a wider safety margin and median lethal dose $\left(\mathrm{LD}_{50}\right)$ value is greater than $2000 \mathrm{mg} / \mathrm{kg}$ in mice.

\section{Discussion}

People customarily use plant(s) or plant-derived preparations considering them to be efficacious against diarrheal disorders without any scientific basis to explain the action of such plants [34]. The aim of the present study was to experimentally evaluate the folkloric acclaimed use of $M$. kummel fruits, which are regarded to confer protection in 
TABLE 4: In vivo antidiarrheal indices of $80 \% \mathrm{MeOH}-\mathrm{E}$ and solvent fractions of $M$. kummel fruits.

\begin{tabular}{|c|c|c|c|c|c|}
\hline Extracts & Dose administered & $\begin{array}{l}\text { Delay in defecation (time of } \\
\text { onset in min, Dfreq) (\%) }\end{array}$ & $\begin{array}{c}\text { Gut meal travel } \\
\text { distance (Gmeq) (\%) }\end{array}$ & $\begin{array}{c}\text { Purging frequency in } \\
\text { number of wet stools } \\
\text { (Pfreq) }(\%)\end{array}$ & $\begin{array}{l}\text { Antidiarrheal } \\
\text { index (ADI) }\end{array}$ \\
\hline \multirow{4}{*}{ 80\% MeOHE } & $100 \mathrm{mg} / \mathrm{kg}$ & 51.14 & 57.66 & 71.40 & 59.49 \\
\hline & $200 \mathrm{mg} / \mathrm{kg}$ & 110.53 & 63.14 & 76.70 & 81.19 \\
\hline & $400 \mathrm{mg} / \mathrm{kg}$ & 149.65 & 68.98 & 85.70 & 96.00 \\
\hline & $3 \mathrm{mg} / \mathrm{kg}$ loperamide & 180.10 & 66.06 & 79.40 & 98.12 \\
\hline \multirow{3}{*}{$\begin{array}{l}\text { Solvent } \\
\text { fractions }\end{array}$} & $\mathrm{CF} 100 \mathrm{mg} / \mathrm{kg}$ & 35.41 & 11.83 & 9.76 & 15.99 \\
\hline & $\mathrm{CF} 200 \mathrm{mg} / \mathrm{kg}$ & 62.69 & 24.73 & 31.41 & 36.52 \\
\hline & $\mathrm{CF} 400 \mathrm{mg} / \mathrm{kg}$ & 90.28 & 32.05 & 39.18 & 48.40 \\
\hline \multirow{3}{*}{$\begin{array}{l}\text { Solvent } \\
\text { fractions }\end{array}$} & $\mathrm{n}-\mathrm{BF} 100 \mathrm{mg} / \mathrm{kg}$ & 66.13 & 19.15 & 19.65 & 29.20 \\
\hline & $\mathrm{n}-\mathrm{BF} 200 \mathrm{mg} / \mathrm{kg}$ & 92.16 & 31.06 & 45.06 & 50.53 \\
\hline & $\mathrm{n}-\mathrm{BF} 400 \mathrm{mg} / \mathrm{kg}$ & 131.65 & 42.20 & 56.82 & 68.09 \\
\hline \multirow{3}{*}{$\begin{array}{l}\text { Solvent } \\
\text { fractions }\end{array}$} & $\mathrm{AF} 100 \mathrm{mg} / \mathrm{kg}$ & 74.29 & 36.92 & 60.82 & 55.05 \\
\hline & $\mathrm{AF} 200 \mathrm{mg} / \mathrm{kg}$ & 114.09 & 49.47 & 68.59 & 72.88 \\
\hline & AF400 mg/kg & 130.07 & 56.45 & 70.59 & 80.33 \\
\hline $\begin{array}{l}\text { Solvent } \\
\text { fractions }\end{array}$ & $3 \mathrm{mg} / \mathrm{kg}$ loperamide & 153.58 & 63.77 & 80.35 & 92.32 \\
\hline
\end{tabular}

$80 \% \mathrm{MeOH}-\mathrm{E}=80 \%$ methanolic extract, $\mathrm{CF}=$ chloroform fraction, $\mathrm{n}-\mathrm{BF}=\mathrm{n}$-butanol fraction, and $\mathrm{AF}=\mathrm{aqueous}$ fraction.

TABLE 5: Phytochemicals in 80\% MeOH-E and solvent fractions of M. kummel fruits.

\begin{tabular}{lcccc}
\hline Secondary metabolites & $\begin{array}{c}\text { Crude extract } \\
80 \% \text { MeOH-E }\end{array}$ & Chloroform fraction & $\begin{array}{c}\text { Solvent fraction } \\
\text { n-Butanol fraction }\end{array}$ & Aqueous fraction \\
\hline Saponins & + & - & - & + \\
Tannins & + & - & - & + \\
Steroids & - & + & - & - \\
Phenols & + & + & + & + \\
Flavonoids & + & + & - & - \\
Alkaloids & + & - & - \\
Terpenoids & + & - & - \\
Anthraquinones & - & - & - \\
Glycosides & - & & - \\
\hline
\end{tabular}

$80 \% \mathrm{MeOH}-\mathrm{E}=80 \%$ methanol extract, $+=$ present, and $-=$ absent.

diarrhea in Ethiopian traditional medicine. Solvent fractions and $80 \% \mathrm{MeOH}-\mathrm{E}$ of $\mathrm{M}$. kummel fruits were substantiated with scientific evidence on the possible mode of action for their antidiarrheal activities.

In Ethiopia, fruits of $M$. kummel are consumed in the traditional medical practice of gastrointestinal abnormalities [15]. In the present study, authors selected $80 \%$ methanol to extract the fruits for secondary metabolites efficiently. The solvent fractions were employed to differentiate the predominant types of secondary metabolites with a better pharmacological activity [35].

In the current study, there was a statistically significant $(p<0.05)$ reduction in number and weight of fecal output and delayed onset of diarrhea in the test groups. The $80 \%$ $\mathrm{MeOH}-\mathrm{E}$ tested at $100 \mathrm{mg} / \mathrm{kg}, 200 \mathrm{mg} / \mathrm{kg}$, and $400 \mathrm{mg} / \mathrm{kg}$ significantly inhibited the frequency of defecation droppings when compared with untreated control mice $(p<0.05)$.
The significant reduction in frequency of defecation, weight of wet stools, and weight of total stools signifies the efficacy of $80 \% \mathrm{MeOH}-\mathrm{E}$ of $\mathrm{M}$. kummel fruits as antidiarrheal agent. This result is in support of previous claims in respect of antidiarrheal medicinal plants.

The aqueous, n-butanol, and chloroform fractions produced antidiarrheal effects in all parameters in castor oil induced diarrheal model, with the aqueous fraction being the most active fraction. In addition, both aqueous and nbutanol fractions significantly decreased the number of wet and total feces and weight of both wet and total stooling at $200 \mathrm{mg} / \mathrm{kg}$ as compared with the negative control $(p<$ 0.05). The chloroform fraction significantly decreased the number of wet and total feces but not weight of both wet and total stooling at $200 \mathrm{mg} / \mathrm{kg}$ dose. Its low dose, $100 \mathrm{mg} / \mathrm{kg}$, had significant effect in altering only the onset of diarrhea when compared with the negative control $(p<0.05)$. The 
insignificant activity of the chloroform fraction for some parameters at the low dose might be due to the inability of secondary metabolites to reach sufficient concentration. This argument is supported by the fact that activity would be apparent with increasing dose of the fraction. This could possibly suggest the localization of the active ingredients in the aqueous and n-butanol fractions. Moreover, it is plausible to assume that more polar secondary metabolites could be responsible for impact on the diarrheal parameters (onset of diarrhea, number of wet stools, total number of stools, weight of wet stools, and weight of total stools). This study was in line with other studies in which the aqueous and nbutanol fractions of different plants reduced the number and weight of stooling [36-38]. Generally, the fractions showed differences in potency in castor oil induced diarrheal model in the rank order of aqueous fraction $>n$-butanol fraction $>$ chloroform fraction in all parameters. The difference in rank order of potency could emanate from the differential distribution of the secondary metabolites as depicted in Table 5.

In the present study, it was shown that the $80 \% \mathrm{MeOH}-$ E significantly suppresses the propulsion of charcoal marker at all tested doses as compared with negative control. The percentage of inhibition of charcoal marker at $400 \mathrm{mg} / \mathrm{kg}$ dose $(68.98 \%)$ of this extract was observed to be almost comparable to the standard drug $(66.06 \%$ at the dose of $3 \mathrm{mg} / \mathrm{kg}$ ). This finding suggests that the extract has ability to influence the peristaltic movement of intestine thereby indicating presence of an intestinal antimotility activity. This decrease in motility facilitates the absorption of electrolytes and then water [39], which might be responsible for the decrease in the number and weight of wet feces observed with the extract. Both aqueous and n-butanol fractions had statistically significant antispasmodic effects with the highest effect revealed at $400 \mathrm{mg} / \mathrm{kg}$ of aqueous fraction $(56.45 \%$, $p<$ $0.05)$. Even though the chloroform fraction had a significant effect on the charcoal meal test, it failed to show a significant effect on number and weight of wet feces, particularly at the low dose. This could be explained by the fact that antimotility effect might not be a necessary and sufficient factor for counteracting diarrhea and it should be supplemented with a certain degree of antisecretory activity.

In the present study, enteropooling model was employed to assess the impact of test fractions and extract on secretory components of diarrhea. In this model, the $80 \% \mathrm{MeOH}-$ $\mathrm{E}$, aqueous, and $\mathrm{n}$-butanol fractions significantly reduced the average volume and weight of intestinal contents at all tested doses when compared with the negative control group ( $p<0.05)$. These findings support the evidence for the extract and fractions' antidiarrheal action to be mediated by antisecretory mechanism. On the contrary, the chloroform fraction had a significant inhibition of intestinal fluid accumulation only at the high dose $(400 \mathrm{mg} / \mathrm{kg})$. This further supports the significant activity of these fractions on the number and weight of wet feces on the castor oil induced diarrheal model, which is in agreement with other studies by which the antienteropooling effects of the extract are related to its antidiarrheal effect [40]. In fact, the ability of chloroform fraction to reduce the volume and weight of intestinal contents only at $400 \mathrm{mg} / \mathrm{kg}(p<0.05)$ lends further support to the limited antidiarrheal effects in the castor oil induced diarrheal model. The significant inhibition of the castor oil induced enteropooling by aqueous fraction in mice suggests that the extract probably produces relief in diarrhea through its spasmolytic and antienteropooling effects. These findings are in consonance with the observations reported for aqueous leaf extract of Byrsocarpus coccineus (Connaraceae) [41] and for aqueous whole plant extract of Mezoneuron benthamianum (Caesalpiniaceae) [42]. This may promote reabsorption of materials in the intestine due to decrease propulsion of material in the intestinal tract.

The in vivo ADI is a measure of the combined effects of three parameters such as delay in onset of diarrheal stools, intestinal motility, and purging frequency in number of wet stools $[43,44]$. Generally, high ADI value indicates a measure of how much effective an extract is in treating diarrhea $[45,46]$. The highest in vivo ADI value was produced by the $80 \% \mathrm{MeOH}-\mathrm{E}$ at its high dose which is directly related to its antidiarrheal activity in all of the three models. This reinforces the notion that the extract is endowed with best antidiarrheal activity compared with solvent fractions. Moreover, the aqueous fraction showed the highest ADI value at its maximum dose as compared with the other fractions. Conversely, the chloroform fraction, which had little antidiarrheal activity in all models, exhibited the lowest $\mathrm{ADI}$, pointing to the fact that $\mathrm{ADI}$ is a useful parameter in ranking antidiarrheal agents.

In the present investigation, the acute toxicity profile of the fruits of M. kummel was determined based on OECD guideline 425 [33], which recommends the use of minimal number of experimental animals. The $\mathrm{LD}_{50}$ for the $80 \%$ $\mathrm{MeOH}-\mathrm{E}$ was found to be $>2000 \mathrm{mg} / \mathrm{kg}$. Generally, if the $\mathrm{LD}_{50}$ value of the test chemical is more than 3 -fold of the minimum effective dose, the test substance can therefore be categorized under experimentally safe substances [47]. Since the $80 \% \mathrm{MeOH}-\mathrm{E}$ had $\mathrm{LD}_{50}$ value of more than three times of the minimum effective dose $(100 \mathrm{mg} / \mathrm{kg})$, it can be taken as a good candidate for further studies. According to the World Health Organization hazard classification systems based on $\mathrm{LD}_{50}$, the $80 \% \mathrm{MeOH}-\mathrm{E}$ of the fruits of $M$. kummel with $\mathrm{LD}_{50}>2000 \mathrm{mg} / \mathrm{kg}$ might be designated as "slightly hazardous" or "unlikely to present acute hazard" taking into consideration of the species similarity between rats and mice [48].

\section{Conclusion}

The results of the present study revealed that $80 \% \mathrm{MeOH}-\mathrm{E}$ of M. kummel fruits is endowed with a promising antidiarrheal activity. Moreover, all the three fractions possessed varying degree of antidiarrheal activity, with the aqueous fraction being the most active followed by the n-butanol fraction and then chloroform fraction in all the three models used in the current study. These findings provide scientific evidence for the next lead compound discovery and development undertakings from $M$. kummel fruits, which have multiple modes of action of antidiarrheal action. 


\section{Abbreviations}

$\begin{array}{ll}\text { ADI: } & \text { Antidiarrheal index } \\ \text { 80\% MeOH-E: } & \text { 80\% methanolic extract } \\ \text { GI: } & \text { Gastrointestinal } \\ \text { LD }_{50}: & \text { Median lethal dose } \\ \text { OECD: } & \text { Organization for Economic Cooperation } \\ & \text { and Development } \\ \text { WHO: } & \text { World Health Organization. }\end{array}$

\section{Data Access}

Data is available at Addis Ababa University Institutional Repository in a form of graduate student thesis (http://etd .aau.edu.et/handle/123456789/11148).

\section{Ethical Approval}

The study was approved by the Scientific and Ethics Review Committee of the Department of Pharmacology, School of Medicine, College of Health Sciences, Addis Ababa University, Ethiopia. The handing of animals was conducted in accordance with international guidelines of the care and use of laboratory animals.

\section{Conflicts of Interest}

The authors declare that there are no conflicts of interest.

\section{Authors' Contributions}

Mulugeta Molla conceived, designed, and conducted experiment, acquired, analyzed, and interpreted data, and drafted manuscript; Negero Gemeda supervised the study and reviewed the final manuscript; Solomon M. Abay supervised the study and prepared and reviewed the final manuscript.

\section{Acknowledgments}

The authors thank the Ethiopian Public Health Institute for hosting the experiment at the Pharmacology Laboratory of the Traditional and Modern Medicine Research Directorate. The research work was financially supported by School of Graduate Studies, Addis Ababa University.

\section{References}

[1] C. L. Fischer Walker, D. Sack, and R. E. Black, "Etiology of diarrhea in older children, adolescents and adults: a systematic review," PLoS Neglected Tropical Diseases, vol. 4, no. 8 article e768, 2010.

[2] S.-X. Zhang, C.-L. Yang, W.-P. Gu et al., "Case-control study of diarrheal disease etiology in individuals over 5 years in southwest China," Gut Pathogens, vol. 8, no. 1 article 58, 2016.

[3] S. Sweetser, "Evaluating the patient with diarrhea: a case-based approach," Mayo Clinic Proceedings, vol. 87, no. 6, pp. 596-602, 2012.

[4] B. C. Mims and C. E. Curry, "Constipation diarrhea and irritable bowel syndrome," in Pharmacotherapy: Prnciples and Practice,
M. A. Chisholm-burns, B. G. Wells, T. L. Schwinghammer et al., Eds., pp. 307-321, McGraw-Hill, New York, NY, USA, 2008.

[5] S. Manatsathit, H. L. Dupont, M. Farthing et al., "Guideline for the management of acute diarrhea in adults," Journal of Gastroenterology and Hepatology, vol. 17, no. 1, pp. S54-S71, 2002.

[6] B. Mims and C. Curry, "Constipation, diarrhea and irritable bowel syndrome," in Pharmacotherapy Priniciples and practice, C.-B. Marie, W. Barbara, S. Terry et al., Eds., pp. 314-316, McGraw-Hill, New York, NY, USA, 1999.

[7] H. Maclehose, H. Bergman, S. Nagpal, E. Goldberg, and F. Pitan, "Vaccines for preventing rotavirus diarrhoea: vaccines in use," Cochrane Database of Systematic Reviews, vol. 11, Article ID CD008521, 2012.

[8] S. A. Madhi, N. A. Cunliffe, D. Steele et al., "Effect of human rotavirus vaccine on severe diarrhea in African infants," The New England Journal of Medicine, vol. 362, no. 4, pp. 289-298, 2010.

[9] G. Prats, B. Mirelis, T. Llovet, C. Muñoz, E. Miró, and F. Navarro, "Antibiotic resistance trends in enteropathogenic bacteria isolated in 1985-1987 and 1995-1998 in Barcelona," Antimicrobial Agents and Chemotherapy, vol. 44, no. 5, pp. 1140-1145, 2000.

[10] G. Yismaw, S. Abay, D. Asrat, S. Yifru, and A. Kassu, "Bacteriological profile and resistant pattern of clinical isolates from pediatric patients, Gondar University Teaching Hospital, Gondar, Northwest Ethiopia," Ethiopian Medical Journal, vol. 48, no. 4, pp. 293-300, 2010.

[11] C. Y. Meng, B. L. Smith, L. Bodhidatta et al., "Etiology of diarrhea in young children and patterns of antibiotic resistance in Cambodia," Pediatric Infectious Disease Journal, vol. 30, no. 4, pp. 331-335, 2011.

[12] A. Tariq, S. Mussarat, M. Adnan et al., "Ethnomedicinal evaluation of medicinal plants used against gastrointestinal complaints," BioMed Research International, vol. 2015, Article ID 892947, 14 pages, 2015.

[13] B. Abera, "Medicinal plants used in traditional medicine by Oromo people, Ghimbi District, Southwest Ethiopia," Journal of Ethnobiology and Ethnomedicine, vol. 10, no. 1, article 40, 2014.

[14] R. Baltussen and Y. Ye, "Quality of care of modern health services as perceived by users and non-users in Burkina Faso," International Journal for Quality in Health Care, vol. 18, no. 1, pp. 30-34, 2006.

[15] T. Teklehaymanot and M. Giday, "Ethnobotanical study of medicinal plants used by people in Zegie Peninsula, Northwestern Ethiopia," Journal of Ethnobiology and Ethnomedicine, vol. 3, article 12, 2007.

[16] R. H. M. Lemmens, "Mimusops kummel Bruce ex A.DC”, in Plant Resources of Tropical Africa, D. Louppe and A. OtengAmoako, Eds., pp. 377-383, Backhuys Publisher, Leiden, The Netherlands, 2008.

[17] C. Jackuleuline, Antimicrobial activity, acute toxicity and phytochemical composition of four medicinal plants traditionally used in sotik sub-county, University of Nairobi, Kenya, 2015.

[18] S. W. Kim, K. R. Peck, S.-I. Jung et al., "Pseudomonas aeruginosa as a potential cause of antibiotic-associated diarrhea," Journal of Korean Medical Science, vol. 16, no. 6, pp. 742-744, 2001.

[19] W. M. Koné, M. Vargas, and J. Keiser, "Anthelmintic activity of medicinal plants used in Côte d'Ivoire for treating parasitic diseases," Parasitology Research, vol. 110, no. 6, pp. 2351-2362, 2012. 
[20] F. Capasso, N. Mascolo, A. A. Izzo, and T. S. Gaginella, "Dissociation of castor oil-induced diarrhoea and intestinal mucosal injury in rat: effect of $\mathrm{N}^{G}$-nitro-L-arginine methyl ester," British Journal of Pharmacology, vol. 113, no. 4, pp. 11271130, 1994.

[21] N. Mascolo, A. A. Izzo, F. Barbato, and F. Capasso, "Inhibitors of nitric oxide synthetase prevent castor-oil-induced diarrhoea in the rat," British Journal of Pharmacology, vol. 108, no. 4, pp. 861-864, 1993.

[22] National Research Council, Guide for the Care and Use of Laboratory Animals, The National Academies Press, Washington, DC, USA, 8th edition, 2001.

[23] S. Umer, A. Tekewe, and N. Kebede, "Antidiarrhoeal and antimicrobial activity of Calpurnia aurea leaf extract," $B M C$ Complementary and Alternative Medicine, vol. 13, article 21, no. 1, 2013.

[24] Y. Maniyar, P. Bhixavatimath, and N. V. Agashikar, "Antidiarrheal activity of flowers of Ixora Coccinea Linn. in rats," Journal of Ayurveda and Integrative Medicine, vol. 1, no. 4, pp. 287-291, 2010.

[25] A. J. Akindele, O. A. Salako, and U. V. Ohonbamu, "Evaluation of the antidiarrhoeal activity of the hydroethanolic leaf extract of Pupalia lappacea Linn. Juss. (Amaranthaceae)," Journal of Ethnopharmacology, vol. 151, no. 2, pp. 984-989, 2014.

[26] A. Ara, M. M. Salehe-e-en, N. Ahmed, M. Hashem, and S. Bachar, "Anti-diarrheal activity and acute toxicity of methanolic bark extract of Adenanthera pavonina Linn (Fabaceae) and its elemetal composition," Turkish Journal of Pharmaceutical Sciences, vol. 10, pp. 263-272, 2013.

[27] M. Rahman, A. Islam, M. Chowdhury, M. Uddin, and A. Jamil, "Antidiarrheal activity of leaves extract of microcos Paniculata linn in mice," International Journal of Green Pharmacy, vol. 2, pp. 21-25, 2012.

[28] A. Degu, E. Engidawork, and W. Shibeshi, "Evaluation of the anti-diarrheal activity of the leaf extract of Croton macrostachyus Hocsht. ex Del. (Euphorbiaceae) in mice model," BMC Complementary and Alternative Medicine, vol. 16, p. 379, 2016.

[29] T. Yacob, W. Shibeshi, and T. Nedi, "Antidiarrheal activity of 80 $\%$ methanol extract of the aerial part of Ajuga remota Benth (Lamiaceae) in mice," BMC Complementary and Alternative Medicine, vol. 16, no. 1, article no. 303, 2016.

[30] S. Bhandary, S. N. Kumari, V. S. Bhat, and M. Prasad Bekal, "Preliminary Phytochemical Screening of Various Extracts of Punica Granatum Peel, Whole Fruit and Seeds," Nitte University Journal of Health Science, vol. 2, no. 4, 2012.

[31] S. Sasidharan, Y. Chen, D. Saravanan, K. M. Sundram, and L. Yoga Latha, "Extraction, isolation and characterization of bioactive compounds from plants' extracts," African Journal of Traditional, Complementary and Alternative Medicines, vol. 8, no. 1, pp. 1-10, 2011.

[32] S. F. Zohra, B. Meriem, S. Samira, and M. S. Alsayadi Muneer, "Phytochemical screening and identification of some compounds from mallow," Journal of Natural Product and Plant Resources, vol. 2, no. 4, pp. 512-516, 2012.

[33] OECD, Test, No. 425: Acute Oral Toxicity: Up-and-Down Procedure, OECD Publishing, Paris, France, 2008.

[34] A. H. Atta and S. M. Mouneir, "Evaluation of some medicinal plant extracts for antidiarrhoeal activity," Phytotherapy Research, vol. 19, no. 6, pp. 481-485, 2005.
[35] S. M. Colegate and R. J. Molyneux, Bioactive Natural Products: Detection, Isolation, and Structural Determination, CRC Press, London, 1993.

[36] S. L. Wansi, E. P. Nguelefack-Mbuyo, M. L. Nchouwet et al., "Antidiarrheal activity of aqueous extract of the stem bark of Sapium Ellipticum (Euphorbiaceae)," Tropical Journal of Pharmaceutical Research, vol. 13, no. 6, pp. 929-935, 2014.

[37] S. Panda, D. Das, and N. Tripthanthy, "Antidiarrhoeal activity of various root extracts of Gmelina Arborea Roxb. in experimentally induced diarrhoea in mice," World Journal of Pharmacy and Pharmaceutical Sciences, vol. 4, no. 4, pp. 912-919, 2015.

[38] P. Reddy, J. Rao, and K. Rao, "Pharmacological evaluationof antidiarrheoeal activity of Momordica cymbalaria," Indian Journal of Pharmaceutical Science \& Research, vol. 5, pp. 136-138, 2015.

[39] A. J. Kent and M. R. Banks, "Pharmacological management of diarrhea," Gastroenterology Clinics of North America, vol. 39, no. 3, pp. 495-507, 2010.

[40] I. R. P. de Sales, F. D. F. Machado, A. F. Marinho, A. S. S. C. Lúcio, J. M. B. Filho, and L. M. Batista, "Cissampelos sympodialis Eichl. (Menispermaceae), a medicinal plant, presents antimotility and antidiarrheal activity in vivo," BMC Complementary and Alternative Medicine, vol. 15, no. 1, article 253, 2015.

[41] A. J. Akindele and O. O. Adeyemi, "Evaluation of the antidiarrhoeal activity of Byrsocarpus coccineus," Journal of Ethnopharmacology, vol. 108, no. 1, pp. 20-25, 2006.

[42] H. O. C. Mbagwu and O. O. Adeyemi, "Anti-diarrhoeal activity of the aqueous extract of Mezoneuron benthamianum Baill (Caesalpiniaceae)," Journal of Ethnopharmacology, vol. 116, no. 1, pp. 16-20, 2008.

[43] Z. Hussain, G. Amresh, S. Singh, and C. V. Rao, "Antidiarrheal and antiulcer activity of Amaranthus spinosus in experimental animals," Pharmaceutical Biology, vol. 47, no. 10, pp. 932-939, 2009.

[44] S. Okpo, F. Ching, and I. Ekeleme, "Evaluation of the antidiarrhoeal activity of the aqueous extract from leaves of Pterocarpus santalinoides," Research Journal of Pharmaceutical, Biological and Chemical Sciences, vol. 2, no. 3, pp. 590-597, 2011.

[45] F. Ching, E. Omogbai, R. Ozolua, and S. Okpo, "Antidiarrhoeal activities of aqueous extract of Stereospermum kunthianum (Cham, Sandrine Petit) stem bark in rodents," African Journal of Biotechnology, vol. 7, pp. 1220-1225, 2008.

[46] S. K. Prasad, D. Laloo, R. Kumar, A. N. Sahu, and S. Hemalatha, "Antidiarrhoeal evaluation of rhizomes of Cryptocoryne spiralis Fisch. ex Wydler: antimotility and antisecretory effects," Indian Journal of Experimental Biology, vol. 52, no. 2, pp. 139-146, 2014.

[47] M. Sisay, E. Engidawork, and W. Shibeshi, "Evaluation of the antidiarrheal activity of the leaf extracts of Myrtus communis Linn (Myrtaceae) in mice model," BMC Complementary and Alternative Medicine, vol. 17, no. 1, p. 103, 2017.

[48] World Health Organization, The WHO Recommended Classification of Pesticides by Hazard and Guidelines to Classification 2009, Wissenschaftliche Verlagsgesellschaft mbH, Stuttgart, Germany, 2010. 


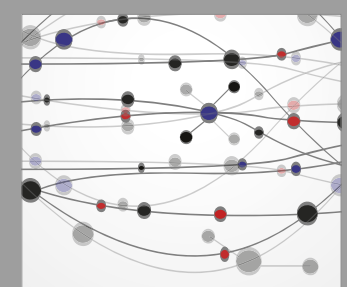

The Scientific World Journal
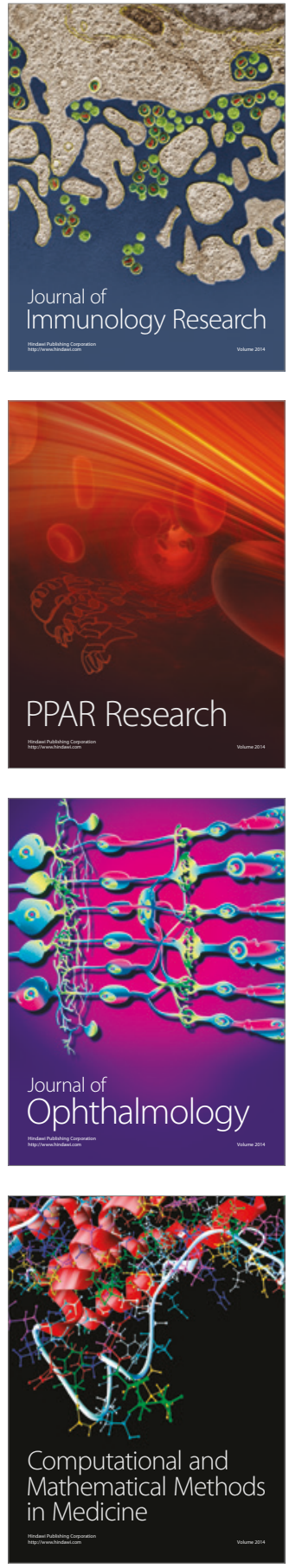

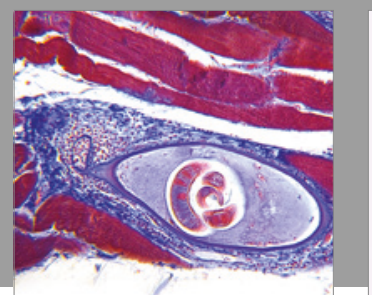

Gastroenterology Research and Practice
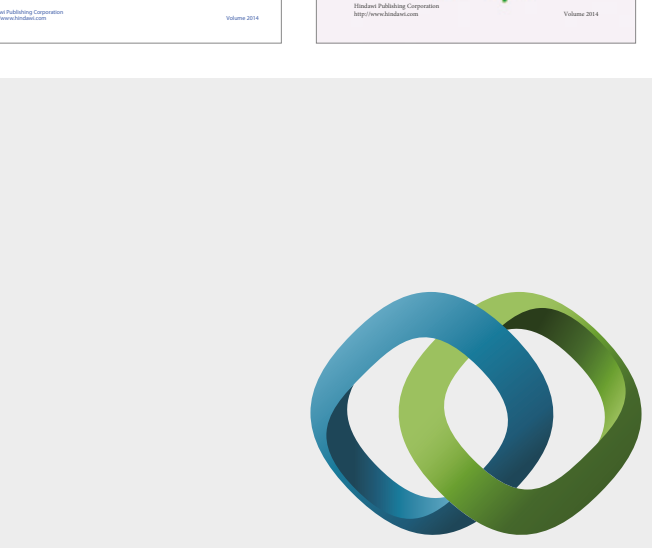

\section{Hindawi}

Submit your manuscripts at

https://www.hindawi.com
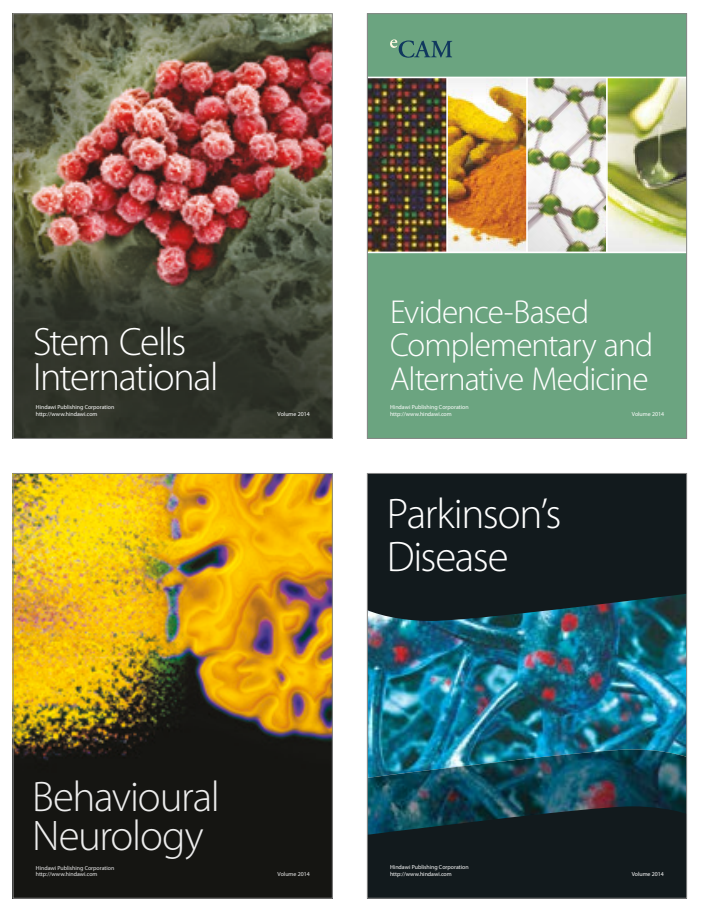
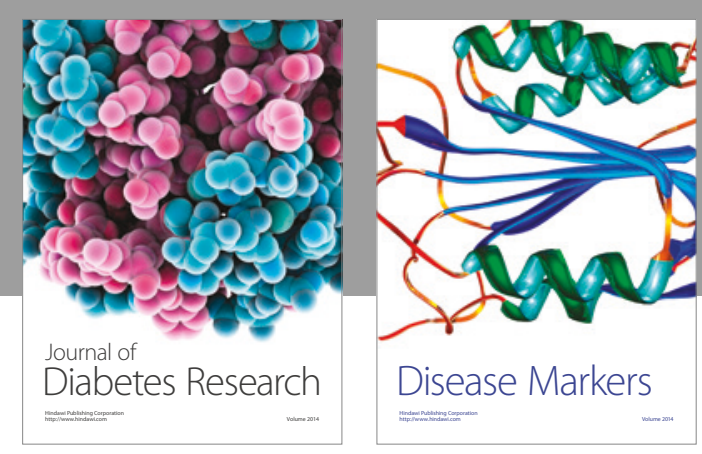

Disease Markers
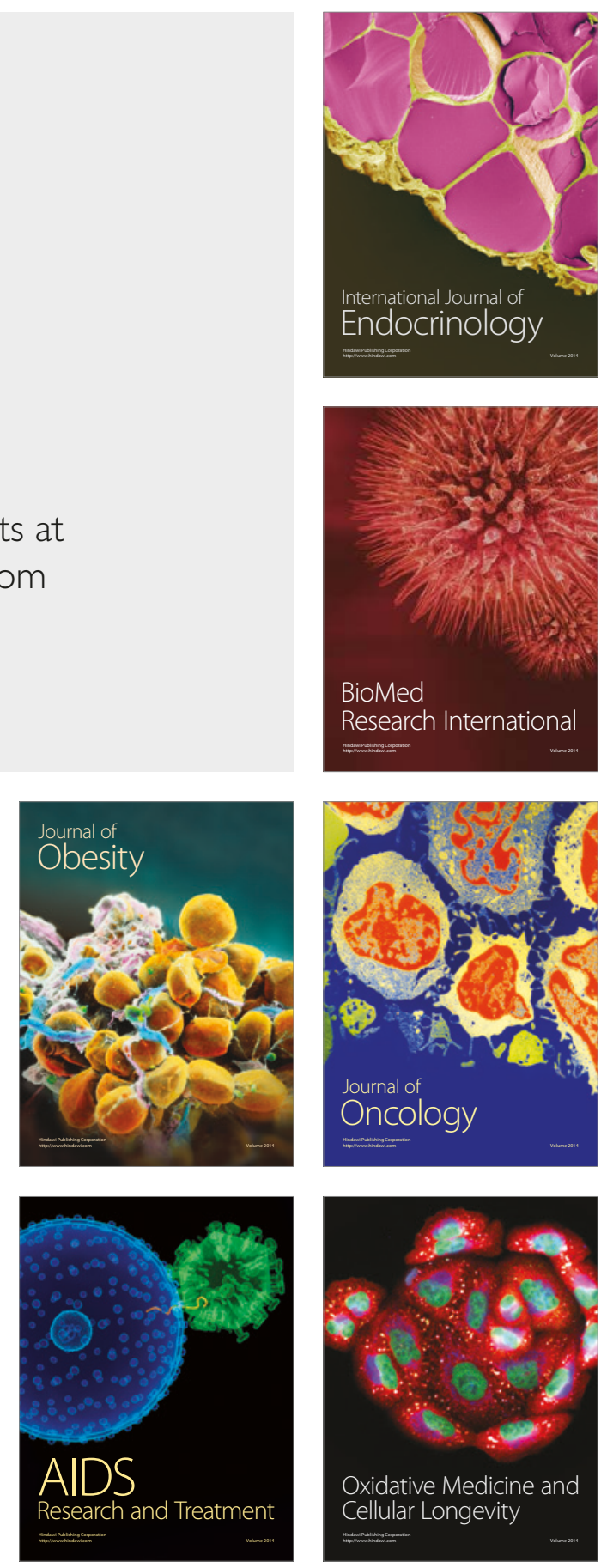